\title{
Exorphins in urine from schizoaffective psychotics
}

\author{
Dag Tveiten ${ }^{1}$, Karl L. Reichelt ${ }^{2^{*}}$ \\ ${ }^{1}$ Biomedical Laboratory, Sandvika, Norway \\ ${ }^{2}$ Department of Pediatric Research, Oslo University Hospital, Oslo, Norway \\ Email: ${ }^{*}$ karlr@ulrik.uio.no, ${ }^{*}$ Karl.L.Reichelt@,rr-research.no
}

Received 23 March 2012; revised 21 April 2012; accepted 30 April 2012

\begin{abstract}
Hyperpeptiduria and opioid excess have been reported in schizophrenia. According to Prof. Dr. L. Lindström, Sweden opioids may explain the pathophysiology of this syndrome. Therefore it is critical to elucidate the presence and nature of opioids in schizophrenia and diagnostic sub groups. First morning urine from untreated schizoaffective patients (ICD-10: F 25.1) was separated on HPLC and peaks that elute where different opioid standards appear, freeze dried, re-dissolved in methanol/water (50/50) and $10 \mathrm{mM}$ formic acid. Mass spectrometry and MS/MS or fragmentation mass spectrometry was performed. We found fragmentation pattern of beta-casomorphin 1 3 and 1 - 4 (bovine) identical to synthetic standards from Bachem. The aggregation tendency of peptides was much in evidence. The reported exorphins were found in the urine from 8 of 12 untreated schizoaffective patients.
\end{abstract}

Keywords: Exorphins; Schizoaffective; Peptide; Mass-Spectrometry

\section{INTRODUCTION}

Increased peptide levels in urine of schizophrenic patients have been found [1-4]. Co-chromatography of exorphins with the use of different gradients on HPLC, was also reported [4,5]. Furthermore the amino acids released on acid hydrolysis indicated that the peptides contained the expected amino acids [5], but tryptophan was destroyed by acid hydrolysis. Opioid increase in schizophrenia has been found by several groups [1-4]. A Swedish group has convincingly described symptoms of schizophrenia related to level of opioid receptor binding opioids [6]. They also demonstrated human casomorphin increase in post partum psychosis [7], which is a very symptom rich psychosis and a depressed state. An increased peptide levels in urine from depressed patients [8] has also been found. With the availability of mass spec-

${ }^{*}$ Corresponding author. trometry and fragmentation mass spectrometry (MS/MS), the final proof of the presence and structure of various peptides, is possible. If the peptide fragmentation patterns are identical to that of synthetic standards, this is like a finger print in forensics. Urine was examined since excess of low MW compounds will usually mean overflow to the urine, and urine is a very convenient body fluid to study for the patients. Hyperpeptiduria is usually dependent on deficient break down [8].

\section{PATIENTS AND METHODS}

We have over many years collected first morning urines from patients with DSM III and IV or IDC 10 diagnosed Schizophrenia. Schizoaffective depressive type psychosis (IDC 10: F25.1) was diagnosed by the leaders of Oslo Univ. Hospital., departments of psychiatry. Not treated patients were 12 of which 9 were females and 3 males, and with an age range of $37-58$ years. It is very difficult to get hold of untreated patients, hence the total was only 12. These patients though severely depressed (hospitalized) also had a running dialogue with "a voice", and paranoid ideation with peculiar language constructions and mannerisms. The typical social withdrawal and self-centered introversion was also present as well as rigid rituals.

Controls were hospital staff, members of The Royal guard regiment in Oslo, and student volunteers, without close relatives suffering from depression, schizophrenia or other CNS disorders. Their age range was 37 - 57: and in all 30 persons. Although adult males have lower peptide levels than females; we have here combined these with the use of 15 male and 15 female volunteers.

There is often considerable difference in eluting pattern from one patient to the next with the same diagnosis. Batches of five urines with the same diagnosis were therefore collected and re-analyzed. This trick should ensure that peaks relevant to the disease studied and common to the disorder would stay the same or increase in size, while individual peptide peaks ought to be diluted out (decrease). This technique was learned from P. Shattock o.b.e., The Autism Research Unit, Sunderland 
Univ., Sunderland, UK.

The fractions that appeared where synthetic standards eluted from the HPLC column or were found increased in collective HPLC re-runs, were freeze dried and kept at $-15^{\circ} \mathrm{C}$.

\section{URINE PREPARATION}

First morning urine was prepared as described [9]. Briefly: First morning urine was frozen as soon as possible at $-15^{\circ} \mathrm{C}$. In the laboratory they were left to thaw over night in the cold room at $4^{\circ} \mathrm{C}$ and $\mathrm{pH}$ was measured at room temp. Creatinin was determined at the Department for Medical Chemistry at Rikshospitalet (accredited). $0.8 \mathrm{ml}$ urine was pre-treated by centrifugation through a $0.22 \mu \mathrm{m}$ Cellulose acetate filter in a Spin XCentrifuge tube (Costar 8161) at $3500 \times \mathrm{g}$ for 20 minutes at room temp. A urine volume equivalent to 250 nanomoles creatinin was analyzed by HPLC on reverse phase c-18 columns (Vydac C-18 peptide/protein column No. 201SP 54 and $0.5 \times 25 \mathrm{~cm}$ ) at $30^{\circ} \mathrm{C}$. (TFA) Trifluoroacetic acid $(10 \mathrm{mM})$ and an acetonitril gradient was used, and an elution rate of $1 \mathrm{ml} / \mathrm{min}$. After a $15 \mathrm{~min}$ initial isocratic run to remove most amino acids and salts [10], a linear gradient was run from $1 \%$ to $60 \%$ acetonitril in water as described [9]. It is essential to have $10 \mathrm{mM}$ TFA in the organic buffer to avoid steeply ascending baseline. Detection of eluting substances was performed at $215 \mathrm{~nm}$ (peptide bonds), $280 \mathrm{~nm}$ (aromatic groups) and $325 \mathrm{~nm}$ (Indolyl groups). In addition to point of elution we found it useful to take the $215 / 280 \mathrm{~nm}$ ratio to help with routine identification of the different peaks. Formic acid is too weak as an anion to split peptide-peptide or peptideprotein aggregates, except at concentration higher than $0.25 \mathrm{M}[11]$.

\section{MASS SPECTROMETRY}

The freeze dried material from peaks that had demonstrated co-chromatography with standards or increase in area after collective HPLC runs, were dissolved in 50\% methanol in water by volume and $10 \mathrm{mM}$ formic acid. We use locally the Pesciex quadropole with ionization in both positive and negative mode. Direct injection by micro-pump was used. It was critical to optimalize the declustering potential and collision potential for each peptide or standard used. This is to avoid splitting of the proline rich peptides by the declustering potential on ordinary MS runs as well as too much aggregation.

\section{ETHICAL CONSIDERATION}

The Ethical committee for south-eastern Norway accepted our procedures. No NS. 06270a.

\section{STATISTICS}

Since the number of untreated patients is small we found it best to use non-parametric statistics or the MannWhitney U test, two tailed.

\section{RESULTS}

In Figure 1, the HPLC patterns for a normal and a schizoaffective patient (ICD 10: F25.1) are seen. Total area expressed as mAu under the UV $215 \mathrm{~nm}$ trace. in controls $=238 \pm 86(\mathrm{n}=30)$, while the schizoaffective patients came out with $740 \pm 99(n=12)$ and are different with two tailed $p=0.01$. As in depressions [8] the dominant peptide peaks elute after $48 \mathrm{ml}$ (or minutes) and differ from paranoid schizophrenia where the dominant peaks are eluting earlier (less retarded) [11]. A urine peak corresponding to beta-casomorphin $1-3$ was found at $47.66 \pm 0.77 \mathrm{ml}(\mathrm{n}=8)$ and $\beta$-casomorphin $1-4$ (bovine) eluting at $52.81 \pm 0.76 \mathrm{ml}(\mathrm{n}=9)$ and the same as synthetic peptides from Bachem. The UV215/280 nm for $\beta$-casomorphin $1-3$ was $16.42 \pm 6$, and for (bovine) $\beta$-casomorphin $1-4: 21.93 \pm 1.69$ for standards $(\mathrm{N}=$ $13)$.

However to our surprise both of these peptides eluted also at $61 \mathrm{ml}$, which is very close to where $\beta$-casomorphin (bovine) $1-7$ elutes. This means that they must probably have been aggregates with each other. In the following we show the fragmentation of these peptides from this much retarded peptide peak, which were the same as for the not aggregated peaks (not shown).

In Figure 2, the mass spectrum of standard $\beta$ casomorphin 1 - 4 (bovine) is seen (Synthesized by Bachem, Switzerland). The declustering potential was set to 20 so as to reduce splitting, which we saw at higher potentials. Even so we retained a dimer underlining the problem of adjuncts and aggregation in all peptide work [12].

In Figure 3, the fragmentation pattern (MS/MS) of $\beta$-casomorphin 1 - 3 (Y-P-F, bovine) is seen for synthetic standard in $3 \mathrm{~A}$ and in $3 \mathrm{~B}$ for the peptide isolated from urine of schizoaffective patients. They are identical. The $\mathrm{X}$ axis is expanded in the biological peptide graph (B) to check for more peptide peaks, but none was found.

In Figure 4, the fragmentation pattern is shown for $\beta$ casomorphin 1 - 4 (Y-P-F-P, bovine). Synthetic sample profile is labeled $\mathrm{A}$, and the peptide isolated from schizoaffective urine is labeled B. Again the fragmentation patterns (MS/MS) are the same. The collision energy was decreased from 30 to 20 for B (hence we have more of the intact peptide at $523.3 \mathrm{~m} / \mathrm{z} \mathrm{amu}$ ) The de-clustering potential was 20 . In the upper profile A the collision energy was put at 30 .

In Figure 5, the aggregation tendency is illustrated by the Zwitterion nature of amino acids (and even more so peptides). Attachment to proteins and other macromolecules 

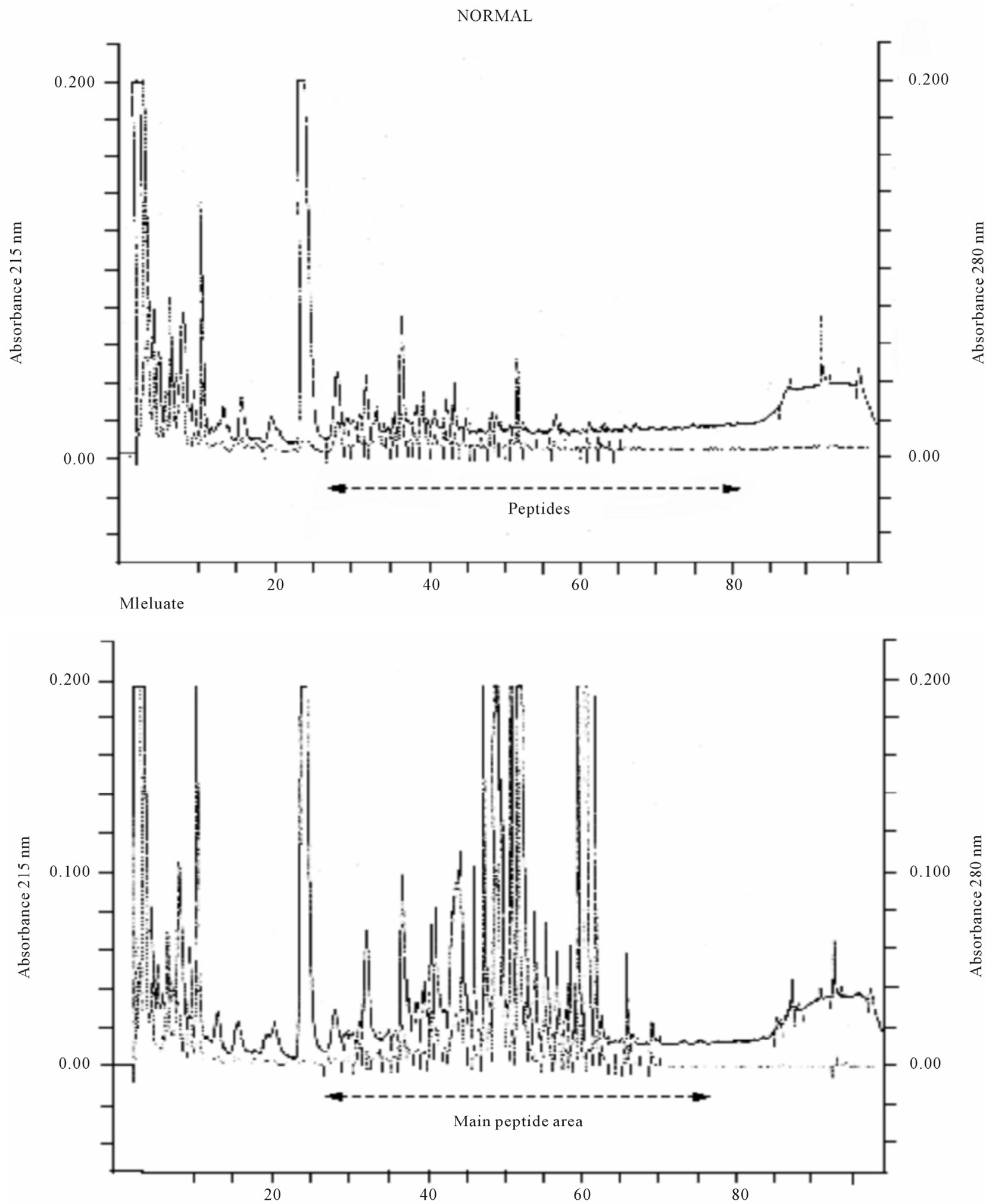

Figure 1. A normal and schizoaffective HPLC pattern equivalent to 250 nanomols creatinin. A typical HPLC profile from a normal and a schizoaffective schizophrenic patient. urine. The ICD 10 diagnosis was F 25.1 and the depressive symptoms were very prominent. C-18 reverse phase column and trifluoroacetic acid (TFA) $10 \mathrm{mM}$ and an acetonotril gradient over 115 minutes, was run at 1 $\mathrm{ml} / \mathrm{min}$. Elution was monitored at $215 \mathrm{~nm}$, for peptide bonds (solid line); $280 \mathrm{~nm}$ for aromatic groups (dotted line). The peaks of material retarded and eluting later than $48 \mathrm{ml}$ dominate as usually seen in Depression [8] in this schizoaffective patient without medication. 


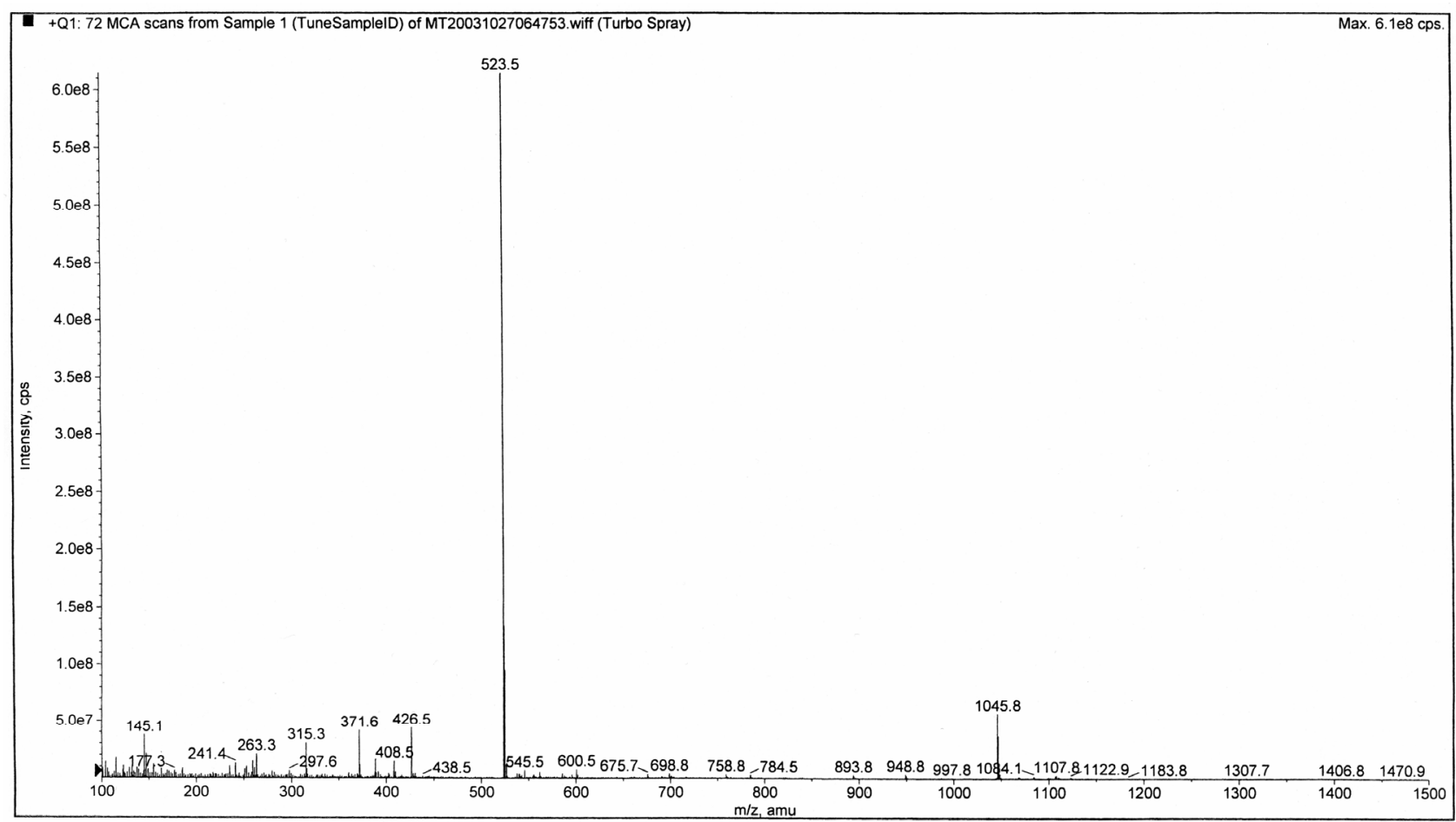

Figure 2. Mass spectroscopy of $\beta$-casomorphin 1 - 4 (bovine) showing the "mother" ion and the dimere. Mass spectrometry of Bovine $\beta$-casomorphin 1 - 4. (Y-P-F-P) The dimer is also seen running the machine with Declusetering potential at 20 . Higher Declustering gave several and more break down products. The peptide was dissolved in 50\% methanol in water and $10 \mathrm{mM}$ formic acid. It illustrates the aggregation tendency of peptides. The aggregate has the same fragmentation pattern as $\beta$-casomorphin 1 - 4 in Figure 4 .

by peptides is extensive $[12,13]$. In addition adducts with Sodium. Potassium and Ammonium are quite common.

\section{DISCUSSION}

The fragmentation pattern of a peptide is like a fingerprint and a rather clear cut demonstration of the presence of a compound. The complete identity of $\beta$-casomorphin (bovine) $1-3$ and $1-4$ found in the urine from schizoaffective and psychotic patients has been shown (Figures 3 and 4). This finding fits similar data from depression reported elsewhere [8]. That most of these peptides present were found in the same peak of material eluting together and later than the standards, demonstrates the problem in peptide work caused by peptide aggregation $[12,13]$. Peptides like amino acids are really Zwitterions as demonstrated in Figure 5. Fairly strong ionic bonds are easily formed. Also side groups that are aromatic can cause olefinic interactions (Phenylalanine, Tyrosine and Tryptophan). Furthermore Lysine, Glutemic acid, Aspartic acid, Serine and Arginine have side groups that may be ionized. In spite of $10 \mathrm{mM}$ formic acid in MS buffer (Figure 2) of standard $\beta$-casomorphin 1 - 4 (bovine), we still see aggregation in the form of a dimere. The simultaneous appearance of beta casomorphin $1-3$ and $1-4$ on the HPLC run in the same retarded peak at $61 \mathrm{ml}$, reinforces this point.
Opioid peptides can act directly on transmitter uptake and release in the CNS [1] and cause behavioural changes $[1-4,14]$ in animals. Furthermore IV $\beta$-casomorphin 1 - 7 (bovine) causes FOS antigen increase in key nuclei of the brain such as the Nucl. Accumbens [15].

However, peptides can act as epitopes by binding to proteins and, or causing conformational changes, and thus induce antibody formation as described against diaminopeptidase IV(CD 26) reducing the efficacy of this enzyme [16]. It is a key enzyme in exorphins break down, and is decreased in depression [17].

Antibodies in serum against gluten, gliadin and casein and also complexes of antibody with these proteins have been found in schizophrenia [18-24], and bipolar disorder [25]. This clearly indicates uptake of these food proteins from the gut in schizophrenia and in depression, and may be a source of these peptides found.

Gastrointestinal peptide uptake is well documented [26,27], and IgA and IgG antibodies may directly demonstrate increased protein uptake. Gut uptake of proteins is also well known [26,28] and the proteins taken up from the gut are found in mothers milk [29,30]. Peptides especially opioids do pass the BBB (blood-brain barrier) $[31,32]$, and especially since the BBB seems deficient in schizophrenia [33].

Antibodies against gliadin caused by gliadin peptides 


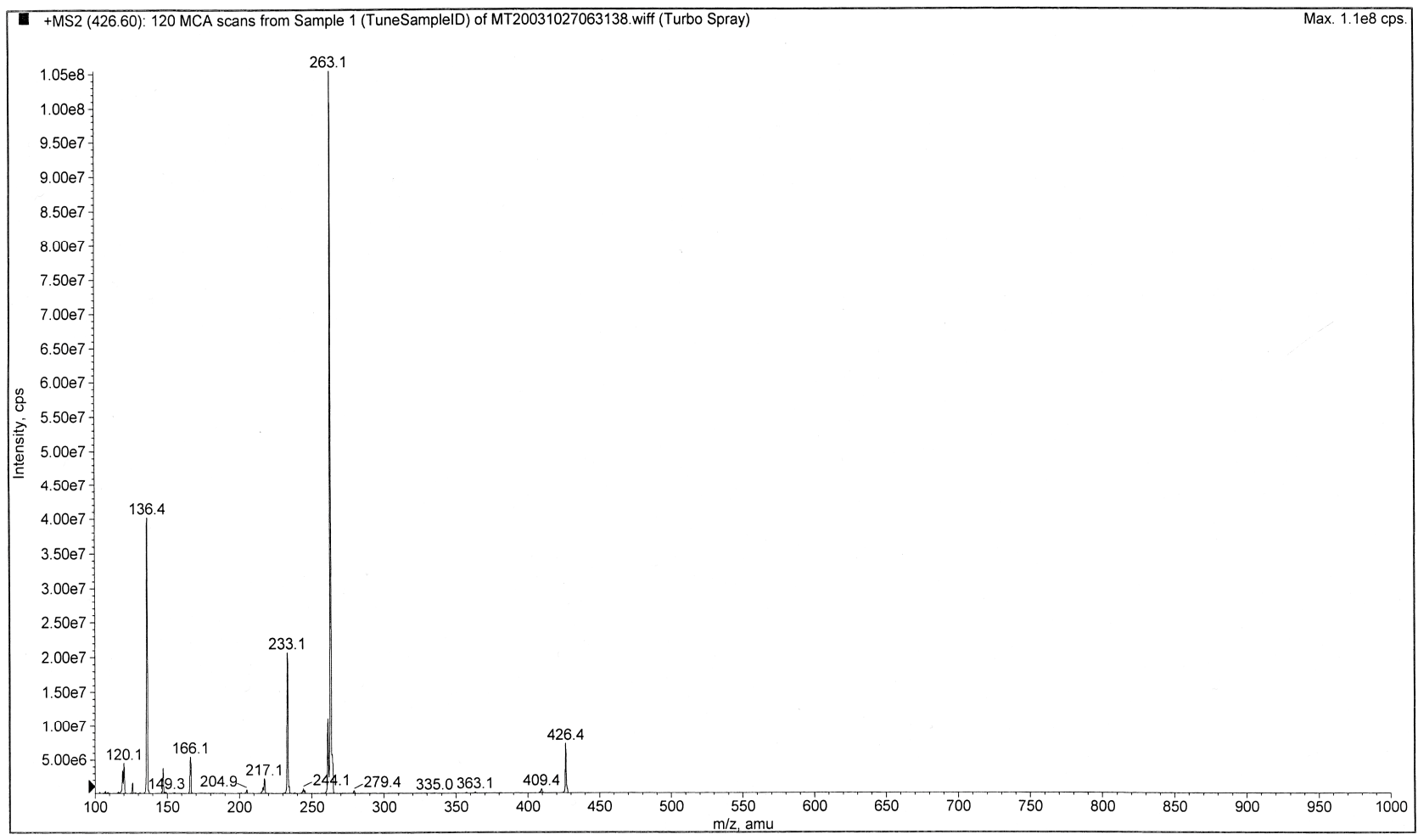

(a)

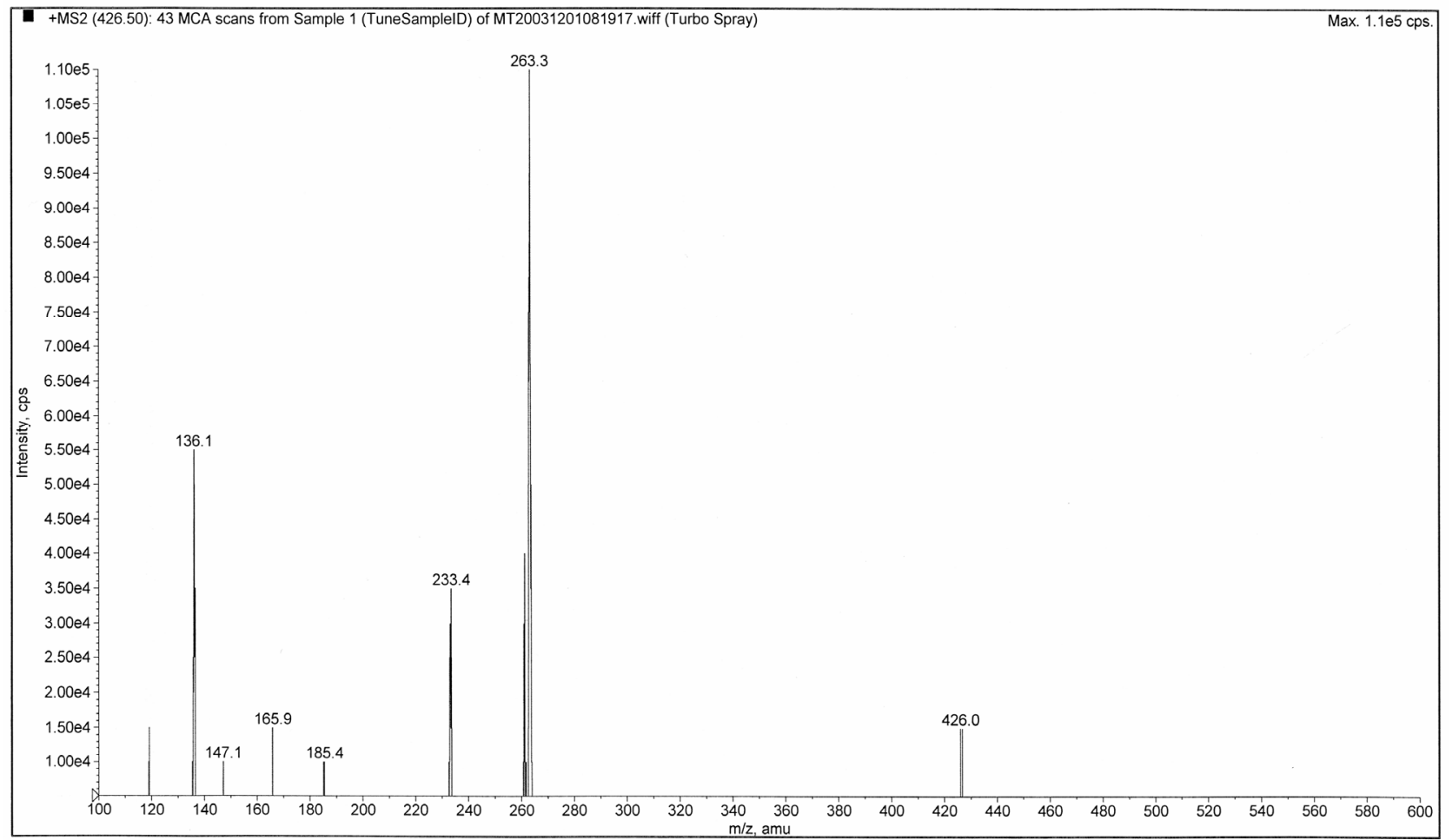

(b)

Figure 3. MS/MS or fragmentation of synthetic $\beta$-casomorphin $1-3$ and the peptide from urine of Schizoaffective patients. $\beta$-casomorphin 1 - 3 fragmentation (MS/MS) pattern is seen. Top trace (a) is synthetic standard from Bachem and trace (b) is from the urine of Schizoaffective persons as described. As the fragmentation pattern is the same, these compounds are of the same. Declustering potential was 10 , Collision potential was 30 . The apparatus is said to have a \pm 0.5 units variation. 


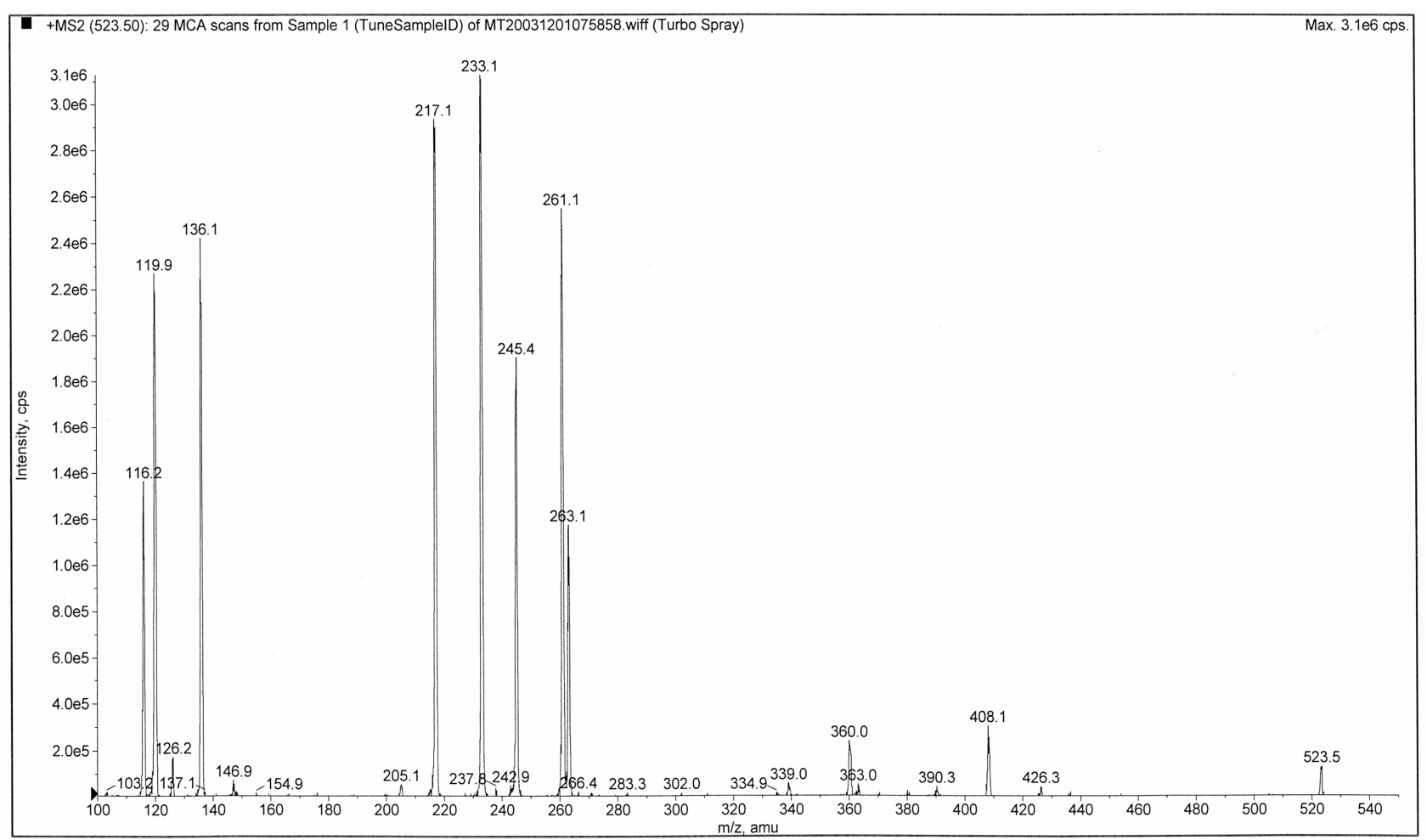

(a)

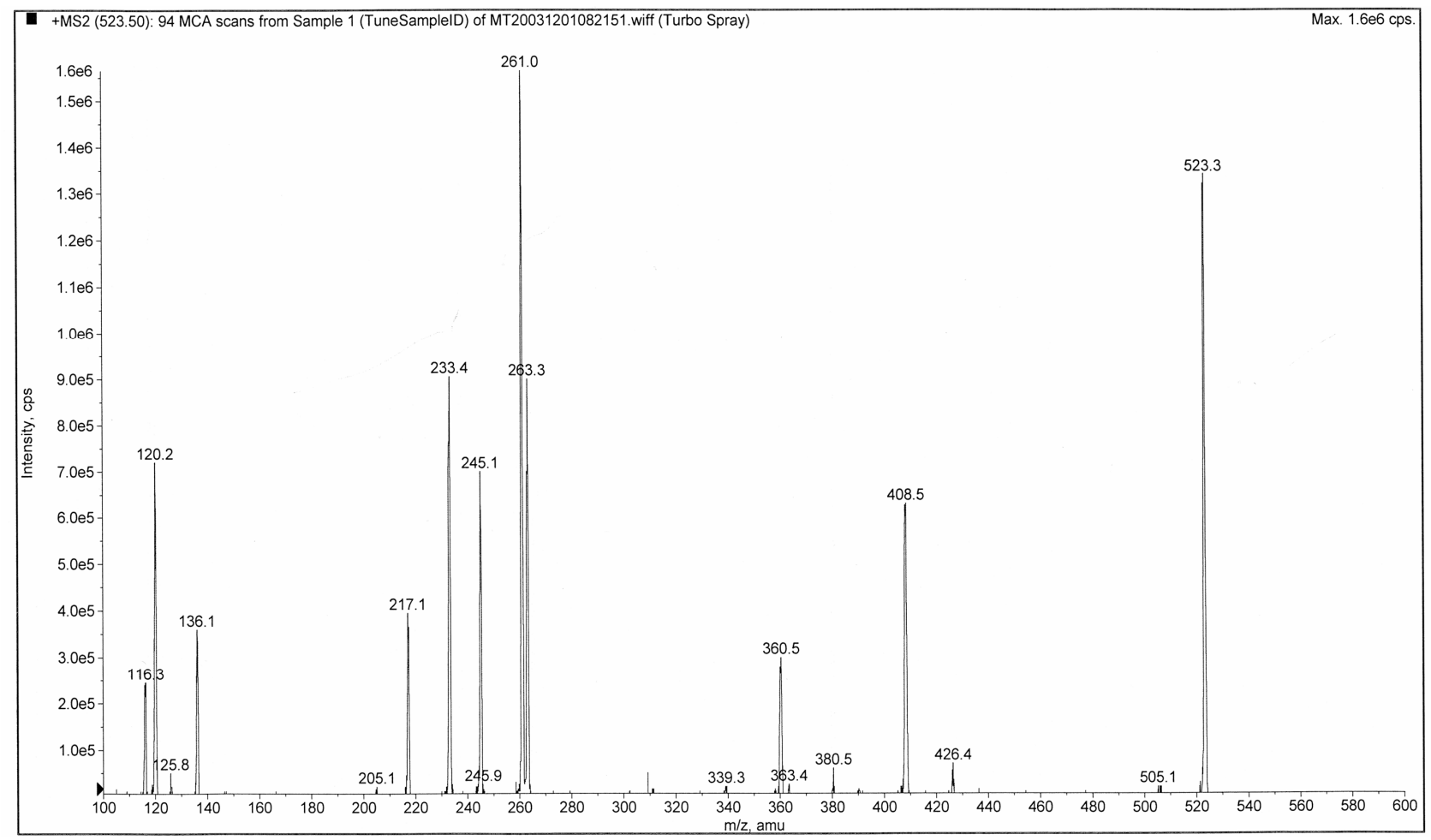

(b)

Figure 4. MS/MS or fragmentation of $\beta$-casomorphin 1 - 4 (bovine). Synthetic (a) and urine derived peptide (b) from schizoaffective patients. (a) is $\beta$-casomorphine 1 - 4 bovine fragmentation pattern (Y-P-F-P). The declustering potential was set at 10 and collision potential at 40; (b) The biological peptide from schizoaffective patients is run with declustering potential at 10, and Collision potential at 30 , hence there is more of the not fragmented intact peptide $(\mathrm{m} / \mathrm{z}$ amu $=523)$. The two runs show a complete match. The abscissa is slightly different for technical reasons. 


\begin{tabular}{|c|c|}
\hline $\begin{array}{r}\text { R } \\
(+) \mathrm{NH}_{3}-\mathrm{C}-\mathrm{C}\end{array}$ & ${ }_{2-\mathrm{C}-\mathrm{COO}(-)}^{\mathrm{R}}$ \\
\hline Lower pH & Higher $\mathrm{pH}$ \\
\hline
\end{tabular}

Figure 5. The zwitter ion nature of amino acids and low MW peptides-(here we show an amino acid). The zwitterion nature of small peptides is illustrated. Actually the Carboxyl group is $\mathrm{C}=\mathrm{O}$ I O- and it can easily be seen that the single bond Oxygen can form ionic bonds. The side group $\mathrm{R}$ if aromatic causes olefinic affinity, and also chargeable side groups as in Lysine, Arginine can form ionic bonds. Induceable dipoles is furthermore known to take place. Displacement of the electrons of the double bond oxygen form such a dipole.

or intact gliadin protein can also have direct effects on brain neurons such as Purkinje cells of the cerebellum [34].

Creatinin is not a very good marker to measure dilution but the best we have got so far, and not too poor in an adult population although influenced by body length and mass as well as $\mathrm{pH}$ (Morkrid, L. personal information).

It was surprising that the Declustering potential could fragment many of the proline rich peptides and the optimal had to be determined in each case. Similarly the collision energy had to be adjusted from one peptide to the next. This was done in steps of 10 .

\section{CONCLUSION}

Exorphins can be found in the urine from some untreated schizo-affective and psychotic patients. This confirms the suggestion by Dohan [35], who first suggested a connection to gliadin and casein to schizophrenia on epidemiological grounds. It also fit our data on depression [8] where increased levels of peptides were found and also opioids. Given the fact that there is a strong genetic input in the schizophrenias [36] it is unavoidable that there must be chemical changes [37]. Since opioids decrease dopaminergic uptake into synaptosomes and cause in vivo dopaminergic hyperactivity [1] the exorphins found may by causing increased dopaminergic function, relate certain food proteins to psychosis.

\section{REFERENCES}

[1] Hole, K, Bergslien, A.A., Jørgensen, H., Berge, O.-G., Reichelt, K.L. and Trygstad, O.E. (1979) A peptide containing fraction from schizophrenia which stimulates opiate receptors and inhibits dopamine uptake. Neuroscience, 4, 1139-1147. doi:10.1016/0306-4522(79)90062-9

[2] Drysdale, A., Deacon, R., Lewis, P., Olly, S., Electricwala, A. and Sherwood, R. (1982) A peptide containing fraction of plasma of schizophrenic patients which binds to opiate receptors and induces hyperactivity in rats.
Neuroscience, 7, 1567-1574. doi:10.1016/0306-4522(82)90265-2

[3] Idet, M., Grof, J., Menyhart, J. and Pajor, A. (1982) Elevated opioid activity in sera of chronic schizophrenia. Acta Physiologica Hungarica, 60, 121-127.

[4] Cade, R., Privette, M., Fregly, M., Rowland, N., Sun Z., Zele, V., Wagemaker, H. and Edelstein, C. (2000) Autism and schizophrenia: Intestinal disorders. Nutritional Neuroscience, 3, 57-72.

[5] Reichelt, W.H. and Reichelt, K.L. (1979) The possible role of peptides derived from food proteins in diseases of the nervous system. In: Gobbi, G., Ed., Epilepsy and Other Neurological Disorders in Celiac Disease, John Libbey \& Comp Ltd., London, 227-237.

[6] Lindström, L.H., Besev, G., Gunne, L.M. and Terenius, L. (1986) CSF levels of receptor active endorphins in schizophrenic patients: Correlation with symptomatology and monoamine metabolites. Psychiatry Research, 19, 93-100. doi:10.1016/0165-1781(86)90001-6

[7] Lindström, L.H., Nyberg, F., Terenius, L., Bauer, K., Besev, G., Lyrenäs, L.M., Wildeck-Lund, E. and Lundberg, B. (2007) CSF and Plasma beta-casomorphin like opioid peptides in postpartum psychosis. American Journal of Psychiatry, 141, 1050-1066.

[8] Liu, Y., Heiberg, T. and Reichelt, K.L. (2007) Towards a possible aetiology for depressions? Behavioral and Brain Functions, 3, 47-53. doi:10.1186/1744-9081-3-47

[9] Reichelt, K.L. and Knivsberg, A.-M. (2003) Can the patho-physiology of autism be explained by the nature of the discovered urine peptides? Nutritional Neuroscience, 6, 19-28. doi:10.1080/1028415021000042839

[10] Böhlen, P., Castillo, F., Ling, R. and Guillemin, R. (1990) An efficient procedure for the separation of peptides from amino acids and salts. Journal of Peptide Research, 16, 306-310.

[11] Reichelt, K.L. and Gardner, M.L.G. (2012) Genetic and dietary factors related to schizophrenia. Open Journal of Psychiatry, 2, 12-20. doi:10.4236/ojpsych.2012.21003

[12] Reichelt, K.L. (2007) Low molecular-Weight peptides. In: Lahti, A., Oja, S.S., Schousboe, A. and Saransaari, P. Eds., Handbook of Neurochemistry and Molecular Neurobiology. Amino-Acids and Peptides in the Nervous System, Springer, New York, 491-511.

[13] Burhol, K., Jensen, T.G., Florholmen, T.G., Jorde, R., Vonen, B. and Olsen, R.I. (1986) Protein-binding and aggregation of somatostatin in human plasma. Italian Journal of Gastroenterology, 19, 1-8.

[14] Sun, Z. and Cade, R.J. (1999) A peptide found in schizophrenia and autism causes behavioral changes in rats. $\mathrm{Au}$ tism, 3, 85-95. doi:10.1177/1362361399003001007

[15] Sun, Z., Cade, R.J., Fregly, M.J. and Privette, R.M. (1999) Beta-casomorphin induces Fos-like immunoreactivity in discrete brain regions relevant to schizophrenia and autism. Autism, 3, 67-83. doi:10.1177/1362361399003001006

[16] Vojdani, A., Pangborn, J.B., Vojdan, I.E. and Cooper, E.L. (2003) Infections, toxic chemicals and dietary pep- 
tides binding to lymphocytes receptors and tissue enzymes are major instigators of autoimmunity in autism. International Journal of Immunopathology and Pharmacology, 16, 189-199.

[17] Maes, M., Demeeester, I., Vanhhof, G., Scharpe, S., Vandervorst, C., Verkerk, R., Minner, B., Suy, E. and Raus, J. (1991) Decreased serum dipeptidyl-peptidase IV activity in depression. Biological Psychiatry, 10, 577-586. doi:10.1016/0006-3223(91)90027-J

[18] Dohan, F.C., Martin, I., Grasberger, J.C., Boehme, D. and Cottrell, J.C. (1972) Antibodies to wheat gliadin in blood of psychiatric patients: Possible role of emotional factors. Biological Psychiatry, 5, 385-399.

[19] Reichelt, K.L. and Landmark, J. (1995) Specific IgA antibody increases in schizophrenia. Biological Psychiatry, 37, 410-413. doi:10.1016/0006-3223(94)00176-4

[20] Dickerson, F., Stallings, C., Origoni, A., Vaughan, C., Khushalani, S., Leister, F., Yang, S., Krivogorsky, B., Alasedini, A. and Yolken, R. (2010) Markers of Gluten sensitivity and celiac disease in recent-onset psychosis and multi-episode schizophrenia. Biological Psychiatry, 58, 100-104. doi:10.1016/j.biopsych.2010.03.021

[21] Samaroo, D., Dickerson, F., Kasarda, D.D., Green, P.H.R., Briani, C., Yolken, R.H. and Alaedini, A. (2010) Novel immune response to gluten in individuals with schizophrenia. Schizophrenia Research, 118, 248-255. doi:10.1016/j.schres.2009.08.009

[22] Jin, S., Wu, N., Xu, Q., Zhang, X., Ju, G.-Z., Law, M.H. and Wei, J. (2011) A study of circulating gliadin antibodies in schizophrenia among Chinese population. Schizophrenia Bulletin, 37, 748-752.

[23] Niebuhr, D.W., Li,Y., Cowan, D.N.,Weber, N.S., Fisher, J.A., Ford, G.M. and Yolken, R. (2011) Association between bovine casein antibody and new onset schizophrenia among US military personnel Association between bovine casein antibody and new onset schizophrenia among US military personnel. Schizophrenia Research, 128, 51-55. doi:10.1016/j.schres.2011.02.005

[24] Severance, E.G., Lin, J., Sampson, H.A., Gimenez, G., Dickerson, F.B., Halling, M., Gresitt, K., Halle, J., Stallings, C.R., Origoni, P.P., Dupont, D. and Yolken, R.H. (2011) Dietary antigens, epitope recognition, and immune complex formation in recent onset psychosis and long-term schizophrenia. Schizophrenia Research, 126, 43-50. doi:10.1016/j.schres.2010.12.001

[25] Severance, E.G., Dupont, D., Dickerson, F.B., Stallings, C.R., Origoni, A.E., Krivgorski, B., Yang, S., Hansnoot, W. and Yolken, R.H. (2010) Immune activation by casein dietary antigens in bipolar disorder. Bipolar Disorders, 12, 834-842. doi:10.1111/j.1399-5618.2010.00879.x

[26] Gardner, M.L.G. (1994) Absorption of intact proteins and peptides. In: Johnson, L.R. Ed., Physiology of the Gas- trointestinal Tract, Raven Press, New York, 1795-1820.

[27] Chabance, B., Marteau, P., Rambaud, J.C., MiglioreSamour, D., Boynard, M., Perrotin, P., Guillet, R., Jolles, P. and Fiat, A.M. (1998) Casein peptides release and passage to the blood in humans during digestion of milk and yogurt. Biochimie, 80, 155-165.

doi:10.1016/S0300-9084(98)80022-9

[28] Husby, S., Jensenius, J.C. and Svenhag, S.E. (1985) Passage of un-degraded dietary antigen into the blood of healthy adults. Scandinavian Journal of Immunology, 22, 83-92. doi:10.1111/j.1365-3083.1985.tb01862.x

[29] Kilshaw, P.J. and Cant, A.J. (1984) The passage of maternal dietary protein into human breast milk. International Archives of Allergy and Applied Immunology, 75, 8-15. doi:10.1159/000233582

[30] Troncone, R., Scarcello, A., Donatiello, A., Cannataro, P., Tabusco, A. and Auricchio, S. (1987) Passage of gliadin into human breast milk. Acta Paediatrica Scandinavica, 76, 453-456. doi:10.1111/j.1651-2227.1987.tb10498.x

[31] Ermisch, A., Brust, P., Kretzchmar, R. and Buhle, H.-J. (1983) On the blood-brain barrier to peptides (3H) betacasomorphin-5 uptake by eighteen brain regions in vivo. Journal of Neurochemistry, 41, 1229-1233. doi:10.1111/j.1471-4159.1983.tb00816.x

[32] Banks, W.A. and Kastin, A.J. (1990) Peptide transport systems for opiates across the blood-brain barrier. American Journal of Physiology, 259, E1-E16.

[33] Kirch, D.G., Alexander, R.C., Suddath, N.R.I., Papadopoulos, N.M., Kaufmann, C.A., Wyatt, D. and Wyatt, R.J. (1992) Blood-CSF barrier permeability and central nervous system immunoglobulin G in schizophrenia. Journal of Neural Transmission, 89, 219-232.

[34] Hadjivassiliou, M., Boscolo, S., Davies-Jones, G.A.B., Grünewald, R.A., Not, T., Sanders, D.S., Simpson, L.E., Tongiorgi, E., Williamson, C.A. and Woodroofe, N.M. (2002) The humoral response in the pathogenesis of gluten ataxia. Neurology, 58, 1221-1226. doi:10.1212/WNL.58.8.1221

[35] Dohan, F.C. (1966) Cereals and schizophrenia.Data and hypothesis. Acta Psychiatrica Scandinavica, 42, 125-152. doi:10.1111/j.1600-0447.1966.tb01920.x

[36] Onstad, B., Skre, I., Torgersen, S. and Kringlen, E. (1991) Twin concordance for DSMIII R Schizophrenia. Acta Psychiatrica Scandinavica, 83, 396-401. doi:10.1111/j.1600-0447.1991.tb05563.x

[37] Reichelt, K.L., Seim, A.R. and Reichelt, W.H. (1996) Could schizophrenia be reasonably explained by Dohan's hypothesis on genetic interaction with a dietary peptide overload? Progress in Neuro-Psychopharmacology \& Biological Psychiatry, 20, 1083-1114. 